\title{
Penerapan Reward dan Punishment Terhadap Pelaksanaan Shalat Subuh Pada Anak di Yayasan Panti Asuhan At-Tanwir Kabupaten Toli-toli
}

\author{
Nurul Zainuddin Ulfa ${ }^{1}$, Andi Muthia Sari Handayani ${ }^{2}$, Adam $^{3}$ \\ Universitas Islam Negeri Datokarama Palu, Indonesia ${ }^{1}$ \\ Q \\ urulzainuddinulfa@gmail.com*
}

\section{Article Information:}

Received September 17, 2020

Revised October 4, 2020

Accepted November 16, 2020

Keywords: Reward dan

Punishment, Shalat Subuh.

\begin{abstract}
Abstrct
Penelitian ini berkenan dengan penerapan reward dan punishment terhadap pelaksanaan shalat subuh pada anak di Yayasan Panti Asuhan At-Tanwir Kabupaten Tolitoli. Jenis penelitian yang digunakan adalah penelitian kualitatif. Adapun teknik pengumpulan data yang digunakan melalui observasi, wawancara dan dokumentasi. Sedangkan analisis menggunakan reduksi, penyajian data dan menarik kesimpulan. Hasil penelitian ini menunjukan bahwa (1). Penerapan reward di Panti Asuhan At-Tanwir diberikan kepada anak-anak yang melaksanakan shalat subuh. Adapun bentuk pemberian yang diberikan kepada anak-anak yang shalat subuh di Panti Asuhan ialah berupa materi yaitu: perlengkapan sehari-hari, sekolah, buku, pakaian, pembayaran SPP bagi yang SMA, sekolah hingga ke perguruan tinggi, serta pemberian pujian dan acungan jempol, (2). Penerapan Punishment di Panti Asuhan diberikan kepada anak-anak yang tidak melaksanakan shalat subuh atau masbuq. Bentuk punishment yang diberikan kepada anak di Panti Asuhan yaitu berupa teguran, pemberian tugas-tugas yaitu mengangkat sisa-sisa makanan selama 2 bulan berturut-turut dan pemberian pukulan, (3). Faktor yang sangat mendukung berjalannya reward dan punishment ini adalah pengelolah Panti Asuhan yang mempunyai komitmen yang kuat untuk menegakkan aturan mengenai masalah reward dan punishment yang di laksanakan.Dampak dari hasil penerapan reward dan punishment di Panti Asuhan At-Tanwir berdampak pada perubahan perilaku yang baik, perubahan perilaku anak terlihat pada saat masuk waktu subuh anak-anak telah bangun dengan sendirinya dan bergegas untuk melaksanakan shalat subuh tepat waktu secara berjamaah.
\end{abstract}

\section{PENDAHULUAN}

Shalat terdiri dari lima waktu, lima waktu itu adalah sebagai berikut: a). Shalat Shubuh: terdiri dari 2 rakaat dimulai dari terbitnya fajar, (hal ini telah disepakati oleh para ulama) dan berakhir dengan terbitnya matahari. b). shalat Dzuhur: terdiri dari 4 rakaat, menurut ijma', permulaan waktu dzuhur adalah ketika matahari bergeser dari posisinya ditengah-tengah langit berdasarkan penglihatan mata. Sementara akhir waktu dzuhur berakhir seiring dengan masuknya awal waktu ashar. c). Shalat Ashar: terdiri dari 4 rakaat, permulaannya adalah ketika ukuran bayangan sesuatu sama panjang dengan ukuran aslinya setelah tergelincir matahari. Adapun waktu ashar adalah tenggelamnya matahari. d). Shalat Magrib: terdiri dari 3 rakaat, ditandai dengan tenggelamnya matahari dan berakhir ketika masuknya waktu isya. e). Shalat Isya: terdiri dari 4 rakaat, waktunya dimulai saat hilangnya mega merah, sementara akhir waktunya adalah sepertiga malam.

$\begin{array}{ll}\text { E-ISSN: } & 2798-3250 \\ \text { Published by: } & \text { Institut Agama Islam Palu }\end{array}$


Masyarakat islam telah menaati perintah shalat ini serta mengajarkannya dari generasi ke generasi tanpa putus hingga kini. Sholat dalam pandangan islam, tidak hanya untuk orang dewasa semata namun juga untuk anak usia 7 tahun (Muchtar, 2008).

Melihat firman Allah dan hadist Nabi tentang shalat, serta manfaat yang diperoleh utamanya ketika mengamalkan shalat subuh, nampaknya menjadi penguat untuk terus melaksanakan shalat subuh secara tepat waktu bagi anak-anak. Akan tetapi dari realitas kehidupan sehari-hari di Yayasan Panti Asuhan At-Tanwir kabupaten Tolitoli, fakta lapangan mengungkapkan bahwa di Panti Asuhan At-Tanwir masih ada sebagian anak-anak yang malas dan terlambat atau masbuq dalam pelaksanaan shalat utamanya shalat subuh. Meskipun demikian, pengelola Yayasan Panti Asuhan At-Tanwir tidak patah arah untuk mengakali agar anak-anak di Yayasan Panti Asuhan At-Tanwir mau rajin shalat subuh. Sebagai orang tua mereka mempunyai tanggung jawab penuh terhadap anak-anaknya, Yayasan At-Tanwir Kabupaten Tolitoli termotivasi untuk menerapkan pemberian Reward (ganjaran/ hadiah) bagi Anak-anak yang melaksanakan Shalat subuh, dan punishment (hukuman) bagi anak-anak yang tidak shalat atau masbuq dalam melaksanakan shalat subuh (Ulfa, 2018).

Reward artinya "ganjaraan, hadiah, penghargaan atau imbalan". Reward sebagai alat pendidikan diberikan ketika seorang anak melakukan sesuatu yang baik, atau telah berhasil mencapai sebuah tahap perkembangan tertentu, atau tercapainya sebuah target. Reward (hadiah) adalah memberikan suatu kepada orang lain sebagai penghargaan. "Hadiah yang diberikan kepada orang lain bisa berupa apa saja, tergantung dari keinginan pemberi atau bisa juga disesuaikan dengan prestasi yang dicapai oleh seseorang" (Purwanto, 2011). Ganjaran adalah alat untuk mendidik anak-anak supaya merasa senang karena perbuatan atau pekerjaannya yang mendapat ganjaran itu baik (Purwanto, 2011).

Menurut Mulyasa reward merupakan respon terhadap suatu perilaku yang dapat meningkatkan kemungkinan terulang kembali perilaku tersebut. hadiah adalah hal yang menggembirakan bagi anak. Reward dapat menjadi pendorong bagi anak dan sebagai motivasi dalam pelaksanaan shalat subuh. Reward atau hadiah juga merupakan respon terhadap suatu tingkah laku yang dapat memungkinkan terulang lagi tingkah laku tersebut (Mulysasa, 2011).

Sementara Punishment diartikan sebagai hukuman atau sanksi. Punishment biasanya dilakukan ketika apa yang menjadi target tertentu tidak tercapai, atau ada perilaku anak yang tidak sesuai dengan norma-norma yang berlaku. Punishment atau hukuman merupakan alat pembelajaran yang bersifat edukatif untuk memperbaiki dan mengarahkan anak-anak kejalan yang benar. Misalnya anak yang tidak melaksanakan shalat subuh maka ia disuruh untuk membersihkan kamar mandi, tidak diberikan uang saku dan tidak diberikan sarapan, hingga hukuman yang tujuannya ialah agar ia menjadi jera dan tidak mengulangi kesalahan yang sama (Alfa, 2018).

Jika reward merupakan bentuk reinforcement yang positif, maka punishment sebagai bentuk reinforcement yang negatif, tetapi jika diberikan secara tepat dan bijak bisa menjadi alat motivasi (Lahagu, 2019). Tujuan dari metode ini adalah menimbulkan rasa tidak senang pada seseorang supaya mereka jangan membuat sesuatu yang jahat. Jadi, hukuman yang dilakukan mesti bersifat pedagogis, yaitu untuk mendidik kearah yang lebih baik (Kosim, 2008).

Penerapan Reward dan Punishment secara tepat maka akan membuat tingkah laku anak seperti yang diinginkan. Reward dimaksudkan sebagai sebuah penguatan yang berbentuk hadiah, sedangkan punishment dimaksudkan dengan pemberian hukuman atas sikap dan perilaku yang dimunculkan oleh anak. Sebenarnya apabila dilihat dari tujuannya antara reward dan punishment pada dasarnya sama, yaitu sebagai sarana atau alat yang dapat membuat seseorang anak mau melakukan perubahan sikap ataupun perilakunya sehingga diharapkan hasilnya lebih baik. Hal yang membedakannya hanyalah bentuknya. Reward lebih berbentuk sesuatu yang menyenangkan karena biasanya berupa "hadiah" barang, sedangkan punishment lebih berbentuk sesuatu yang tidak menyenangkan karena biasanya berupa "hukuman" (Murdoko, 2017). 


\section{METODE PENELITIAN}

Penelitian yang digunakan ini adalah penelitian kuantitatif. Penelitian kuantitatif memandang tingkhalkau manusia dapat diramalkan, objektif dan dapat diukur. Penggunaan penelitian kuantitatif dengan instrumen yang valid dan reliabel serta analisis statistik yang sesuai dan tepat akan menghasilkan penelitian yang tidak menyimpang. Lokasi penelitian skripsi ini di Yayasan Nurul Ihsan Kabupaten Tolitoli. Yayasan ini terletak di jalan Pipit No. 10 kelurahan Tuweley, Kecamatan Baolan.

Dalam penelitian ini menggunakan teknik pengumpulan data observasi, wawancara, dan dokumentasi. Adapun istrumen penelitian yang digunakan dalam wawancara adalah alat tulis menulis untuk mencatat reflektif dan pedoman wawancara. Pedoman wawancara disusun secara tidak terstruktur sebab menutup kemungkinan diluar garis yang akan pewawancara tanyakan akan ada jawaban dari narasumber yang bisa saja mengundang perhatian pewawancara untuk bertanya lebih rinci dan mendalam lagi berkenan dengan hal tersebut

\section{PEMBAHASAN}

Salah satu tokoh psikologi yang memiliki teori tentang perubahan perilaku adalah Albert Bandura. Menurut Bandura, sebagian besar manusia belajar melalui pengamatan secara selektif dan mengingat tingkah laku orang lain (Zainal, 2019). Bandura memandang perilaku individu tidak semata-mata refleks otomatis atas stimulus (S-R Bond), melainkan juga akibat reaksi yang timbul sebagai hasil interaksi antara lingkungan dengan skema kognitif individu itu sendiri.

Bandura menekankan dua hal penting yang sangat mempengaruhi perilaku manusia yaitu pembelajaran observasional (modeling) atau penyajian contoh perilaku dan (imitation) atau peniruan, teori ini juga memandang pentingnya conditioning. Melalui pemberian reward dan punishment, seorang individu akan berpikir dan memutuskan perilaku mana yang perlu dilakukan.

Berdasarkan hasil pengamatan dan wawancara peneliti, bahwa yang menjadi faktor pendukung perubahan perilaku anak adalah lingkungan yang mendukung, adanya figur yang ditiru, dan Pemberian reward dan punishment kepada anak-anak sesuai dengan perbuatannya. Hal ini juga di pertegas oleh ketua yayasan yaitu "anak-anak melihat ada kakak-kakanya yang di kuliahkan, mereka akan menjadikan itu sebagai dorongan dan menjadikannya sebagai contoh. Sebaliknya jika mereka melihat temannya dihukum maka sebisa mungkin mereka menjauhi nya" (Ramli Mahmud, 2019).

Reward diberikan kepada anak-anak yang shalat subuh tepat waktu dan berjamaah, dengan adanya reward anak-anak termotivasi dan membuat anak merasa senang, reward di berikan kepada anak ketika apa yang di targetkan telah di capai. Anak-anak mengetahui bahwa pekerjaan atau perbuatan yang menyebabkan ia mendapat reward itu baik maka dengan sendirinya perbuatan yang baik itu akan terulang. Seperti yang di jelaskan oleh Buchari Alma yaitu reward sebagai respon positif terhadap suatu tingkah laku tertentu dari anak yang memungkinkan tingkah laku tersebut timbul kembali (Buchari Alma, 2018).

Dalam pemberian reward, pengelola yayasan berkomitmen kuat untuk menegakkan aturan mengenai pemberian reward, baik pemberian berupa pujian, maupun materi yang berperan untuk meningkatkan motivasi anak. Dalam pemberian reward pengelola dan anak membuat kesepakatan bersama yang tujuannya agar anak mempertahankan apa yang telah dicapainya. Hal ini seperti yang dikemukakan oleh Megawati Safitri dalam skripsinya Konsep Reward Dan Punishment Dalam Mendidik Anak Di Lingkungan Keluarga Menurut Ajaran Rasulullah Saw yaitu:

a) Reward mempunyai arti mendidik

b) Reward berfungsi sebagai motivasi untuk mengulangi perilaku

c) Reward Berfungsi untuk memperkuat perilaku yang disetujui secara sosial adanya reward yang diberikan digunakan untuk membentuk asosiasi yang menyenangkan dengan perilaku yang diinginkan. 
Pada pelaksanaan shalat subuh di yayasan, masih ada anak yang terlambat dalam pelaksanaan shalat subuh sehingga pihak yayasan menerapkan pemberian punishment, punishment dimaksudkan agar anak menjadi jera dan mengarahkan anak kearah yang benar yang bertujuan agar anak-anak tidak mengulangi perilaku yang tidak di inginkan. Dalam pelaksanaan punishment, pengelola telah membuat kesepakatan bersama anak-anak yang bertujuan untuk meningkatkan efektifitas hukuman tersebut. Pengelola yayasan memberikan hukuman kepada anak-anak yang telah berusia 11 tahun keatas atau kelas 5 keatas, sedangkan untuk anak 11 tahun ke bawah masih dalam proses pembelajaran. Hal ini seperti yang di tulis oleh megawati safitri yaitu " ketika orang tua memberikan punishment, maka orang tua maupun pengelola harus memperhatikan (Safitri, 2017):

a) Pastikan bukan balita yang menerima punishment atau hukuman. Balita belum paham punishment (hukuman).

b) Hindarkan memberikan punishment (hukuman) dalam keadaan emosi.

c) Perhatikan apakah punishment (hukuman) tersebut memiliki efek baik untuk anak.

d) Jelaskan pada anak mengenai sebab-akibat suatu perilaku.

Pemberian punishment berfungsi sebagai motivasi agar anak menjauhi hukuman akibat pengalaman yang tidak menyenangkan yang pernah dialaminya dan sebagai alat untuk menyadarkan anak bahwa perbuatan yaang dilakukan nya itu tidak baik, dengan adanya punishment anak-anak mengetahui tindakan apa saja yang boleh dilakukan dan mana yang tidak boleh dilakukan. Hal ini seperti yang di kemukakan Syaiful Bahri Djamarah yang mana fungsi dari punishment ialah (Djamarah, 2014):

a) Fungsi restriktif

Hukuman dapat menghalangi terulangnya kembali perilaku yang tidak diinginkan pada anak. Jika seorang anak pernah mendapat hukuman karena ia telah melakukan satu kesalahan atau pelanggaran, maka ia akan berusaha untuk tidak mengulangi kesalahan yang serupa di masa datang.

b) Fungsi Pendidikan

Hukuman yang diterima anak merupakan pengalaman bagi anak yang dapat dijadikan pelajaran yang berharga. Anak bisa belajar tentang salah dan benar melalui hukuman yang telah diberikan kepadanya.

c) Fungsi motivasi

Hukuman dapat memperkuat motivasi anak untuk menghindarkan diri dari tingkah laku yang tidak diinginkan. Dari pengalaman hukuman yang pernah diterima anak, maka anak merasakan bahwa menerima hukuman merupakan suatu pengalaman yang kurang menyenangkan, dengan demikian anak bertekad tidak mengulangi kesalahan yang sama dan akhirnya timbul dorongan untuk berperilaku wajar, yaitu perilaku yang diinginkan dan dapat diterima oleh kelompoknya.

Berdasarkan pengamatan dan wanwancara yang peneliti lakukan di yayasan At-Tanwir dalam pelaksanaan shalat subuh yaitu pengelola melihat hasil dari penerapan reward dan punishment yang di terapkan di yayasan dengan melihat anak-anak yang awalnya jika masuk waktu shalat masih harus di bangunkan untuk shalat akan tetapi dengan adanya reward dan punishment ini anak-anak dengan kesadaran masing-masing bangun sendiri pada saat tiba waktu shalat subuh serta bersiap-siap untuk melaksanakan shalat, bahkan anak-anak sampai berlarian agar tidak terlambat untuk shalat berjamaah.

\section{KESIMPULAN}

Berdasarkan hasil penelitian dan pembahasan diatas, maka dapat di simpulkan bahwa:

1. Penerapan reward di Yayasan Panti Asuhan At-Tanwir diberikan kepada anak-anak yang melaksanakan shalat subuh. Adapun bentuk pemberian yang diberikan kepada anak-anak yang shalat subuh di Panti Asuhan ialah berupa materi yaitu: pemenuhan kebutuhan, perlengkapan sehari-hari, sekolah, buku, pakaian, pembayaran SPP bagi yang SMA serta menyekolahkan hingga ke perguruan tinggi, serta pemberian pujian dan acungan jempol. 
2. Penerapan punishment di Yayasan Panti Asuhan At-Tanwir diberikan kepada anak-anak yang tidak melaksanakan shalat subuh atau masbuq. Bentuk punishment yang diberikan kepada anak di Panti Asuhan yaitu berupa teguran atau ancaman, pemberian tugas yaitu mengangkat sisa-sisa makanan selama 2 bulan berturut-turut dan pemberian pukulan.

3. Faktor pendukung dan penghambat pada penerapan reward dan punishment di Yayasan Panti Asuhan At-Tanwir antara lain:

a. Faktor pendukung

Faktor yang sangat mendukung berjalannya reward dan punishment ini adalah pengelolah Yayasan Panti Asuhan yang mempunyai komitmen yang kuat untuk menegakkan aturan mengenai masalah reward dan punishment yang di laksanakan. Kemudian anak-anak yang takut dan penurut serta tumbuh nya kesadaran anak-anak yang sudah menginjak remaja yang tanpa di perintah itu mereka bangun dengan sendirinya dan membantu mengontrol anak-anak yang lain, serta lingkungan yang mendukung

b. Faktor penghambat

Sebagian anak susah bangun, Anak belum tumbuh kesadaran di dalam dirinya bahwa shalat adalah kewajiban khususnya shalat subuh, dan anak terpaksa bangun.

4. Dampak dari hasil penerapan reward dan punishment di Yayasan Panti Asuhan At-Tanwir berdampak pada perubahan perilaku anak, perubahan perilaku anak terlihat pada saat masuk waktu subuh anak-anak telah bangun dengan sendirinya dan bergegas untuk melaksanakan shalat subuh tepat waktu secara berjamaah.

\section{Referensi}

Abdullah, Abdurrahman Saleh. Teori-Teori Pendidikan Berdasarkan Al-Qur'an. Jakarta: Pt Rineka Cipta, 1994.

Alma Buchari. Guru Professional Menguasai Metode Dan Terampil Belajar. Bandung: Alfabeta, 2018

Alni Syafitri, Wawancara, Yayasan At-Tanwir, 10 April 2019

Ari, Donal Ari, et. al, Introduction to Research, diterjemahkan oleh Arief Rahman, Pengantar Penyusunan dan Pendidikan. Surabaya: Usaha Nasional, t. th

Arikunto, Suharsimi. Prosedur Penyusunan Ilmiah: Suatu Pedekatan Praktik. Jakarta: Rineka Cipta,1993.

Bungin Burhan. Penyusunan Kualitatif. Jakarta: Kencana Prenada Media Grup, 2007

Depag RI. Al-Quran Terjemahan. Bandung: Jabal, 2010.

Departemen Pendidikan Dan Kebudayaan. Kamus Besar Bahasa Indonesia. Jakarta: Balai Pustaka, Tt

Departemen Pendidikan Nasional. Kamus Besar Bahasa Indonesia. Cet. II: Jakarta: Balai Pustaka, 2005.

Djamarah, Syaiful Bahri. Pola Komunikasi Orang Tua Dan Anak Dalam Keluarga. Jakarta: Rineka Cipta, 2014.

Hakim, Arif Rahman. Skripsi Pengaruh Pelaksanaan Ibadah Shalat Terhadap Akhlak Siswa Di Smpn Ciputat Tanggerang. Jakarta: Uin Syarif Hidayatullah: 2008.

Harini Sri. Mendidik Anak Sejak Dini. Yogyakarta: Kreasi Wacana, 2003.

Hasan, M Iqbal. Pokok-Pokok Materi Metedologi Penyusunan dan Aplikasinya. Jakarta: Ghalia Indonesia, 2002.

Istadi Irawati. Mendidik Anak Dengan Cinta. Jakarta:Pustaka Inti: 2005 
Ulfa, Handayani \& Adam.

Kardjono Moehari. Mempersiapkan Generasi Cerdas. Jakarta: Qisthi Press, 2008.

Khalil Mustafa. Berjumpa Allah Dalam Shalat, Cetakan 1. Jakarta: Pustaka Zahara 2004.

Kosim Muhammad. Antara Reward Dan Punishment. Padang: Ekspress Rubric Artikel, 2008.

Maleong, Lexy J. Metodologi Penyusunan Kualitatif. Bandung: Remaja Rosda Karya, 1999.

Mas'ud Abdurrahman. Reward Dan Punishment Dalam Pendidikan Islam. Jurnal Media 2006

Muchtar, Heri Jauhari. Fikih Pendidikan. Bandung: PT Remaja Rosdakarya, 2008.

Mulysasa, Menjadi Guru Professional Menciptakan Pembelajaran Kreatif dan Menyenangkan. Bandung: Remaja Rosdakarya, 2011).

Murdoko, E. Widijo Hari. Parenting with Leadership; Peran Orang Tua dalam Mengoptimalkan dan Memberdayakan Potensi Anak. Jakarta: Elex Media Komputindo, 2017.

Nur Wahid, Wawacara, Yayasan At-Tanwir, 11 April 2019

Purwanto Ngalim. Ilmu Pendidikan Teoritis Dan Praktis. Bandung: Remaja Rosdakarya, 2011.

Purwanto, M. Ngalim. Ilmu Pendidikan Teoritis Dan Praktis. Bandung: Remaja Rosdakarya, 2006.

Ramli Mahmud, Wawancara, Kantor Yayasan At-Tanwir, 6 April 2019

Rifa'i Moh. Risalah Tuntunan Shalat Lengkap. Semarang, Cv. Toha Putera: 2003.

Safitri Megawati. Skripsi Konsep Reward Dan Punishment Dalam Mendidik Anak Di Lingkungan Keluarga Menurut Ajaran Rasulullah Saw, (Uin Raden Fatah Palembang: 2017), H. 42H. 44

Suhartono Irawan. Metode Penyusunan Sosial. Bandung: Remaja Rosdakarya, 2002.

Surakhmad Winarto. Pendekatan dalam Proses Belajar Mengajar. Bandung: PT Remaja Rosdakarya, 1978.

Sumiati, Wawancara, Yayasan At-Tanwir, 7 April 2019

Tafsir Ahmad. Ilmu Pendidikan Dalam Perspektif Islam. Bandung: Pt Remaja Rosdakarya, 2011.

Yunus Mahmud, Kamus Arab-Indonesia. Jakarta: Pt. Hidakarya Agung, 1990.

Yusrina, Jihan Avie. Skripsi Studi Analisis Tentang Perintah Shalat Pada Anak Sejak Usia Tujuh Tahun Dalam Perspektif Pendidikan Islam, Semarang: Institut Agama Islam Negeri Walisongo Semarang: 2014.

Zainudin. Seluk Beluk Pendidikan Dari Al-Ghazali. Jakarta: Bumi Aksara, 2007. 